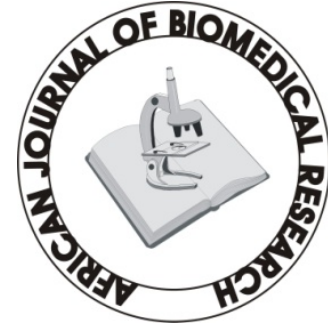

Full-text available at http://www.ajbrui.com http://www.bioline.br/md http://www.ajol.com

Received:

August 2007

Accepted (Revised):

November 2007

Published

January 2008
Full Length Research Article

\section{Thirst Perception and Dryness of Mouth in Healthy Young Adults Nigerians}

\author{
${ }^{1,2}$ Igbokwe, V.U. and ${ }^{2}$ Obika, L.F.O. \\ ${ }^{1}$ Department of Physiology, College of Health Sciences, \\ Usmanu Danfodiyo University P.M.B 02254, Sokoto, Nigeria \\ ${ }^{2}$ Department of Physiology, College of Medicine, \\ P.M.B 1154, University of Benin, Benin City, Nigeria.
}

\section{ABSTRACT}

This study examined the threshold for thirst perception (TP) using the visual analogue scale (VAS). Thirst perception (TP) and dryness of mouth (DM) were studied in normal subjects, $(\mathrm{n}=137 ; 78$ males of height, $1.72 \pm 0.01$, age, $23 \pm 0.26$, body mass index, $21.11 \pm 0.29$, and 59 females of height, $1.65 \pm 0.01$, age, $21 \pm 0.23$, body mass index, $21.0 \pm 0.27)$. The results showed that (i) TP and DM in males, $(1.21 \pm$ $0.15 \mathrm{~cm}$ and $1.14 \pm 0.16 \mathrm{~cm}$ respectively) and in females, $(1.10 \pm$ $0.16 \mathrm{~cm}$ and $1.04 \pm 0.17 \mathrm{~cm}$ respectively) were similar. (ii) The relationship, Thirst $(\mathrm{cm})=0.75$ (plasma arginine vasopressin \pm 1.2 ) exists and has a mean of not thirsty of $1.2 \mathrm{~cm}$ at the lower end of the scale. (iii) The plasma osmolality of $281 \mathrm{mOsm} / \mathrm{kg}$ cannot be the threshold for TP and the plasma osmolality of $285 \mathrm{mOsm} / \mathrm{kg}$ or $284.3 \mathrm{mOsm} / \mathrm{kg}$ cannot be the threshold for plasma arginine vasopressin secretion but rather the mean of the lower set point of the scales for TP and plasma arginine vasopressin $\left[\mathrm{P}_{\mathrm{AVP}}\right]$ secretion. (iv) The threshold for TP using the VAS is between $1.50-1.575 \mathrm{~cm}$ markings, and plasma osmolality of $286.0-286.25 \mathrm{mOsm} / \mathrm{kg}$. $\mathrm{P}_{\mathrm{AVP}}$ of $0.4-0.5 \mathrm{pmol} / \mathrm{l}$ being the sensitivity of the osmoregulatory unit.

(Afr. J. Biomed. Res. 11: 39 - 46)

Key Words; Thirst perception, Dryness of mouth, plasma osmolality, osmotic threshold, Visual Analogue Scale

*Address for Correspondence : vigbokwe5@yahoo.com 


\section{INTRODUCTION}

Definition of thirst has been the subject of much debate, with major disagreement focusing on whether it is a local (for example, pharyngeal) or general sensation (Fitzsimons, 1972). Dryness of the mouth (DM) and throat region is a striking feature in thirst, and some have gone so far as to say that this feeling of dryness of mouth is an essential component of thirst, but very few claim that we drink when we are thirsty solely to abolish the disagreeable sensations that arise in the mouth when salivation is insufficient to keep the mouth and pharynx moist. The evidence being that the sensation of thirst and the sensation of dryness of the mouth could be dissociated from each other (Fitzsimons, 1972). Robertson (1984), defined thirst as 'a generalized deep-seated feeling of a desire for water'. As thus defined, thirst is not synonymous with drinking, because drinking can be affected positively or negatively by a variety of factors such as personal and cultural factors. Also, this terminology is only appropriate for human studies as animals cannot report the sensation of thirst.

Studies of thirst mechanism and dryness of mouth have been hampered by the lack of objective methods of quantification. Estimates of thirst and DM rely solely on the subject's ability to perceive and to report the sensation. Sometimes one can check such information by observing the amount of water drunk spontaneously.

A geometric rating scale was devised by Thompson and Campbell (1977), to quantify acute changes in thirst in controlled experimental settings. Using this method

(Robertson, 1984), assessed the effects of osmotic stimuli on thirst mechanism and vasopressin secretion at various times during the infusion of hypertonic solution in healthy adults. The result showed the function; $\mathrm{P}_{\mathrm{AVP}}=1.48\left(\mathrm{P}_{\text {osm }}-284.7\right) ; \mathrm{r}$ $=0.977$ and Thirst $=9.06\left(\mathrm{P}_{\text {osm }}-293.5\right) ; \mathrm{r}=$ 0.966. According to their analysis the osmotic threshold for the onset of thirst was 293.5 $\mathrm{mOsm} / \mathrm{Kg}$, which is approximately $10 \mathrm{mOsm} / \mathrm{Kg}$ above the osmotic threshold for vasopressin release.
Thompson et al (1986) employing a visual analogue scale (VAS), where subjects defined their own thirst ratings before the experiment rather than be assigned to zero thirst ratings (Rolls et al, 1980), explored the characteristics of osmotically induced thirst throughout a wider range of plasma osmolalities than previously examined. From linear regression analysis of their results, they defined the functions:

Thirst $(\mathrm{cm})=0.3\left(\mathrm{P}_{\text {osm }}-281\right) ; \mathrm{r}=+0.92, \mathrm{P}<$ 0.001 and $\mathrm{P}_{\mathrm{AVP}}(\mathrm{pmol} / \mathrm{l})=0.4\left(\mathrm{P}_{\text {osm }}-285\right) ; \mathrm{r}=$ $+0.96, \mathrm{P}<0.001$. They concluded that $(1)$ the osmolar threshold for thirst onset thus defined (281 $\mathrm{mOsm} / \mathrm{Kg}$ ) is at the lower end of the physiological range of plasma osmolality and was much lower than that quoted in previous studies (Robertson et al, 1976; Baylis \& Robertson, 1980; Robertson, 1984). 2) Thirst perception (TP) rises in a progressive fashion throughout a wide range of plasma osmolalities and that the osmolar threshold for thirst onset (281 mOsm/kg) was similar to the theoretical osmolar threshold for vasopressin release $(285 \mathrm{mOsm} / \mathrm{kg})$.

In the works of Robertson (1984) and Thompson et al (1986) it was not clear whether a linear relationship also exists between thirst $(\mathrm{cm})$ and $\mathbf{P}$ Avp. Also not clear is, what exactly is the range for normal not thirsty markings on the VAS as currently used for the estimation of TP? This study therefore is to, (1) determine normal TP and $\mathrm{DM}$ in young healthy male and female adults using the VAS (2) investigate whether a linear relationship also exists between $\mathrm{TP}$ and $\mathrm{P}$ AVP using the equations of Thompson et al (1986). (3) Determine whether there are differences between the sexes in the responses above and (4) determine the range for normal not thirsty markings on the VAS.

\section{MATERIALS AND METHODS}

\section{Subjects}

Healthy young volunteer males $(\mathrm{n}=78$, age 17-30years) and females ( $\mathrm{n}=59$, age 18-29years) were used in this study following approval by the local Research Ethics committee of the University of Benin, College of Medicine. All the subjects were active but none was athletically trained as 
defined by the absence of a regular physical exercise programme during the last six months before the experiment (Kokkinos et al, 1995).

Exclusion criteria for this study were any history of diabetes and cardio - respiratory disease.

\section{Procedure}

Each subject came to the laboratory on the day of the experiment. Participants completed a general health questionnaire to determine physical fitness, personal and family history of diabetes, heart disease, hypertension and current use of medication. The subject's anthropometric data then were obtained. Body surface area was calculated from height $[\mathrm{H}(\mathrm{cm})]$ and weight $[\mathrm{W}$ (kg)] with the formular of Dubois and Dubois (Peyreigne et al 1998), and the body mass index (BMI), calculated from

$B M I=\frac{W t(\mathrm{~kg}) /}{H^{2}(\mathrm{~cm})}$

Base-line (resting) blood pressure (BP) and heart rate (HR) were measured with the subject in the seated position and after fifteen minutes of rest in the laboratory at a room temperature of $29^{\circ} \mathrm{C}$. The right arm supported at the heart level (Frohlich et al 1988), was used for blood pressure and heart rate measurements. Measurements were made by digital blood pressure and HR monitor (Walgreen's, Model 93). Three basal readings were obtained on each subject at 3-minutes interval and the mean of these readings recorded as the normal blood pressure and heart rate. Mean arterial blood pressure (MABP) was calculated from the formular MABP $=1 / 3$ systolic blood pressure $+2 / 3$ Diastolic blood pressure (Zappe et al, 1996).

\section{Thirst and Dryness of Mouth Rating}

Thirst perception and dryness of the mouth were obtained using the visual analogue scale (VAS) (Thompson et al, 1991, Takamata et al, 1994). Thirst perception and dryness of mouth ratings were defined for statistical purposes as the distance in centimeters of the mark from the "Not thirsty" or 'Not dry' extreme. The visual analogue scale is an indirect approximation of the plasma osmolality (Robertson et al, 1982) which we have not measured in this work.

\section{Statistical Analysis}

Data are presented as means \pm SEM. Differences in TP, DM, WT, HT, BMI, Age, HR, and $\mathrm{BP}$ between the groups were analysed using the unpaired students't-test. The sensations of thirst and dryness of mouth within the groups were also analysed for possible difference using the paired t-test. Changes were considered statistically significant when $\mathrm{p} \leq 0.05$. Regression plot was also done for possible correlation between thirst perception and dryness of mouth.

\section{RESULTS}

The male and female groups studied showed thirst perceptions of $1.21 \pm 0.15$ and $1.10 \pm 0.16$ respectively, while the dryness of mouth was 1.14 \pm 0.16 and $1.04 \pm 0.17$ respectively.

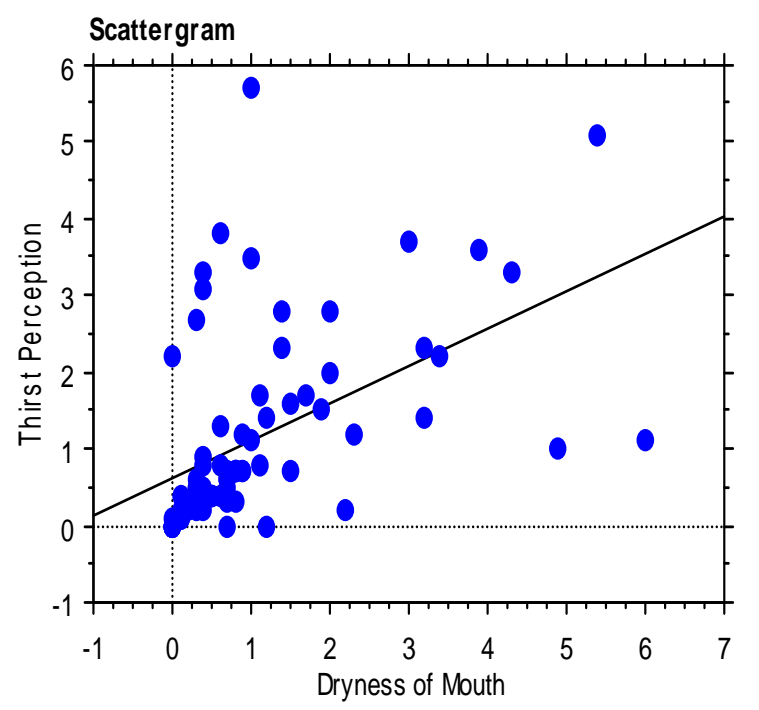

Thirst Perception $=.622+.486$ * Dryness of Mouth; $R^{\wedge} 2=.248$

\section{Figure 1.}

Scatter gram showing the relationship between Thirst Perception (TP) and Dryness of Mouth (DM) in the male group. The regression equation given by the straight line and defining the relationship between Thirst perception and Dryness of Mouth is: $\mathrm{TP}=0.622+0.486 \mathrm{DM}(\mathrm{r}=0.498 ; \mathrm{p}<0.0001)$. 


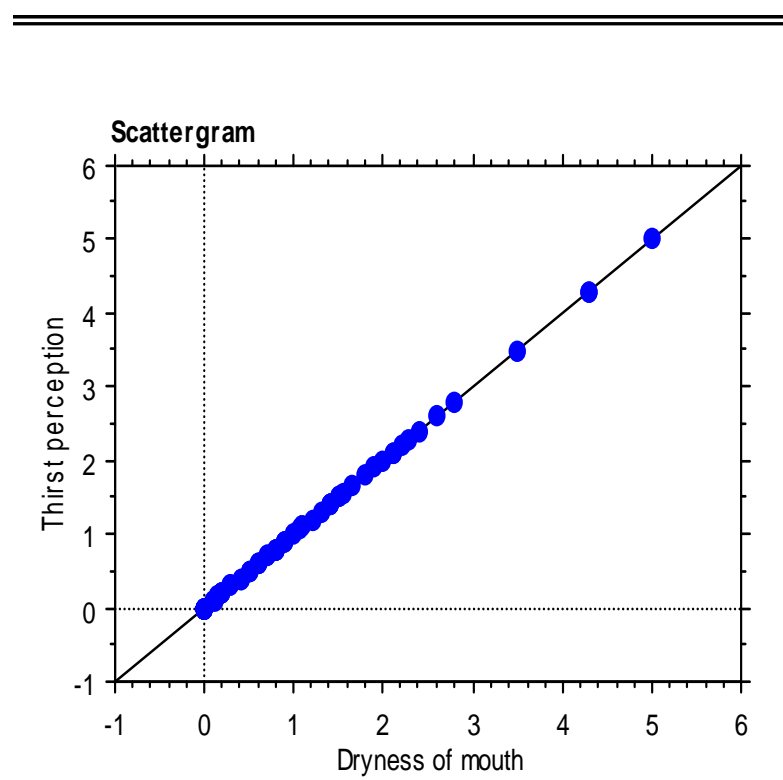

Thirst perception $=0+1$ * Dryness of mouth; $\mathrm{R}^{\wedge} 2=1$

\section{Figure 2.}

Scatter gram showing the relationship between Thirst Perception (TP) and Dryness of Mouth (DM) in the female group. The regression equation given by the straight line and defining the relationship between Thirst perception and Dryness of Mouth is: TP $=0+1$ $\operatorname{DM}(\mathrm{r}=1 ; \mathrm{p}=0)$.

There was no significant difference in thirst perception and dryness of mouth between the male and female groups. They were also of comparable body mass index (male $=21.11 \pm 0.29$, female $=$ $20.70 \pm 0.27$ ). Table 1 gives a summary of their anthropometric data, with their data for thirst perception and dryness of mouth.

\section{DISCUSSION}

This work examined thirst perception and dryness of mouth using the (VAS) visual analogue scale in young male and female adults. The subjects were comparable in body mass index. The VAS, though, might be, susceptible to distortion by a variety of personal, and cultural influences, this method however provides the best available description of the function of the thirst mechanism so far, (Robertson, 1984). It has been shown that thirst ratings using the VAS are highly reproducible within individuals on repeated testing (Thompson et al, 1991).

This work shows a thirst perception (TP) and dryness of mouth (DM) of $1.21 \pm 0.15 \mathrm{~cm}$ and $1.14 \pm 0.16 \mathrm{~cm}$ in males, and $1.10 \pm 0.16 \mathrm{~cm}$ and $1.04 \pm 0.17 \mathrm{~cm}$ in females as 'not thirsty ' and 'not dry' respectively. The TP and DM observed in the male group did not show any significant difference from that of the female group. They were found to be similar to each other. Burrell et al, (1991) reported a value of thirst perception (TP) of $1.3 \pm$ $0.4 \mathrm{~cm}$ and $1.5 \pm 0.4 \mathrm{~cm}$ in experimental and control male subjects respectively as 'not thirsty'.

Table 1. Thirst Perception and Dryness of Mouth, expressed as mean \pm SEM, in the male and female subjects.

\begin{tabular}{|c|c|c|c|c|c|c|c|c|c|}
\hline & $\begin{array}{l}\text { Thirst } \\
\text { Perception } \\
(\mathrm{Tp}) \mathrm{Cm}\end{array}$ & $\begin{array}{l}\text { Dryness } \\
\text { Of Mouth } \\
\text { (Dm) Cm } \\
\end{array}$ & $\begin{array}{l}\text { Weight } \\
\text { (Kg) }\end{array}$ & $\begin{array}{l}\text { Height } \\
\text { (M) }\end{array}$ & $\begin{array}{l}\text { Body Mass } \\
\text { Index } \\
\text { (Bmi) }\end{array}$ & $\begin{array}{l}\text { Body } \\
\text { Surface } \\
\left(\mathbf{M}^{2}\right)\end{array}$ & $\begin{array}{l}\text { Age } \\
\text { (Yrs) }\end{array}$ & $\begin{array}{l}\text { Heart } \\
\text { Rate } \\
\text { (Bpm) } \\
\end{array}$ & $\begin{array}{l}\text { Blood } \\
\text { Pressure } \\
\text { (Mmhg) } \\
\end{array}$ \\
\hline $\begin{array}{l}\text { Male } \\
n=78\end{array}$ & $\begin{array}{c}1.21 \\
\pm \\
0.15\end{array}$ & $\begin{array}{c}1.14 \\
\pm \\
0.16\end{array}$ & $\begin{array}{c}62.8 \\
\pm \\
1.01\end{array}$ & $\begin{array}{c}1.72 \\
\pm \\
0.01\end{array}$ & $\begin{array}{l}21.11 \\
\pm \\
0.29\end{array}$ & $\begin{array}{c}1.74 \\
\pm \\
0.02\end{array}$ & $\begin{array}{c}22.69 \\
\pm \\
0.26\end{array}$ & $\begin{array}{c}69.5 \\
\pm \\
1.04\end{array}$ & $\frac{112 \pm 1.60}{66 \pm 1.57}$ \\
\hline \multirow[t]{2}{*}{$\begin{array}{l}\text { Female } \\
\mathrm{n}=66\end{array}$} & $\begin{array}{l}1.10 \\
\pm \\
0.16\end{array}$ & $\begin{array}{c}1.04 \\
\pm \\
0.17\end{array}$ & $\begin{array}{c}56.2 \\
\pm \\
0.8\end{array}$ & $\begin{array}{c}1.65 \\
\pm \\
0.01\end{array}$ & $\begin{array}{l}20.70 \\
\pm \\
0.27\end{array}$ & $\begin{array}{c}1.61 \\
\pm \\
0.01\end{array}$ & $\begin{array}{c}20.52 \\
\pm \\
0.23\end{array}$ & $\begin{array}{c}77.3 \\
\pm \\
1.66\end{array}$ & $\frac{103 \pm 1.42}{62 \pm 1.00}$ \\
\hline & $\mathrm{p}>0.05$ & $\mathrm{p}>0.05$ & $\mathrm{p}<0.01$ & $\mathrm{p}<0.01$ & $\mathrm{p}>0.05$ & $\mathrm{p}<0.01$ & $\mathrm{p}<0.01$ & $\mathrm{p}<0.05$ & $\frac{p<0.05}{p>0.05}$ \\
\hline
\end{tabular}


Obika et al, (1996) in their work on kolanut activity in young dehydrated subjects reported thirst rating of $2.5 \pm 0.5 \mathrm{~cm}$ in control young subjects as 'not thirsty.' Figaro and Mack (1997) also in their work in dehydrated humans showed ratings of perceived thirst and mouth dryness of $1.5 \pm 0.6 \mathrm{~cm}$ and $0.9 \pm 0.2 \mathrm{~cm}$ as 'not thirsty' and 'not dry' respectively in control subjects. This work therefore is found to correlate very well with the findings of Burrell et al, (1991) and Figaro and Mack (1997).

\section{Correlation between DM and TP}

In this study the sensations of thirst and dryness of mouth in the subjects were analysed for possible correlation using the t-test. The analysis did not show any significant difference between TP and DM either in the respective male and female group or between the groups. It is therefore concluded that using the visual analogue scale (VAS), the sensation of thirst is closely associated with dryness of the mouth. Rolls et al, (1980) on studies of thirst in humans showed that 'normally the subjective sensation of thirst has a very strong oral component described as a dry mouth'. Stachenfeld et al (1996) also showed that subjective ratings of mouth dryness were highly correlated with thirst $(r=0.96)$. The observation of this study therefore conforms with the reports of the above two groups of workers.

The idea that thirst is related to the relative dryness of the mouth dates back to the Greeks (Grossman, 1967). Haller (1764), attributed this sensation to a deficiency of mucus and saliva. Canon (1919) stated that when the salivary glands fail to provide sufficient fluids to moisten the mouth, the local discomfort and unpleasantness which result constitute the feeling of thirst. Studies of the effect on thirst of altering oral sensations or blocking them have shown results consistent with a dry mouth theory (Adolph, 1947; Wolf, 1958; Epstein et al, 1964). However, against this local theory, are experiments demonstrating that there could be a dissociation between DM and TP (Montgomery, 1931; Steggerda, 1941).

Claude Bernard in (1856) prepared horses and dogs with an oesophageal or gastric fistula. When the animals were tested with open fistula, they drank enormous quantities of water (shamdrinking), in spite of the mouth being bathed with large quantities of water. Bellows (1939) confirmed Bernard's early experiments in dogs and observed that during persistent sham-drinking water wets the mouth and therefore the dry mouth theory cannot be correct. Sham drinking had also been seen clinically in 1925 by Gairdner when in attempting suicide a man cut his oesophagus, but not his arteries or veins. After several days he became intensely thirsty, but all the water he drank ran straight out of the oesophagus and produced no relief of thirst. Thirst was, however, relieved by placing water into the lower half of the oesophagus. These evidence indicate that dry mouth and thirst can be dissociated and therefore there must be some other explanation for thirst.

The role of dryness of mouth in thirst, (although shown not a be an essential thirst stimulus), should not be completely disregarded. There is the need to look into, what exactly is the role of dryness of mouth in thirst, as seen in humans, if there is any. Figaro and Mack (1997), Rolls et al, (1980) have suggested that the oropharynx may have a role in the initiation, termination and maintenance of drinking.

\section{Relationship between thirst perception (TP) and Plasma arginine vasopressin $\left(\mathbf{P}_{\mathrm{AVP}}\right)$ Secretion.}

Thompson et al (1986) reported that the osmolar threshold for thirst onset $(281 \mathrm{mOsm} / \mathrm{Kg}$ ) is at the lower end of the physiological range of plasma osmolality and it is similar to the theoretical osmolar threshold for vasopressin release (285 $\mathrm{mOsm} / \mathrm{Kg}$ ). While their work showed a clear linear relationship between plasma osmolality and thirst, and between plasma osmolality and arginine vasopressin, it however was silent on whether there was a linear relationship between plasma arginine vasopressin and thirst.

From Thompson's et al equations (1986), the relationship between thirst and plasma osmolality $\mathrm{P}(\mathrm{osm})$ can be expressed as

$P_{\text {(osm) }}=\frac{T+0.3(281)}{0.3}=\frac{10 T}{3}+281 \ldots \ldots \ldots \ldots \ldots(1)$ 
and the relationship between plasma osmolality and plasma arginine vasopressin $\left(\mathrm{P}_{\mathrm{AVP}}\right)$ can be expressed as:

$P_{(o s m)}=\frac{\left(P_{A V P}\right)+0.4(285)}{0.4}=\frac{10\left(P_{A V P}\right)}{4}+28 \ldots \ldots . .(2)$

since their work was within the same range of plasma osmolality, $280 \quad-320 \mathrm{mOsm} / \mathrm{kg}$, (McKenna and Thompson, 1998; Thompson et al, 1986), equations (1) and (2) relating plasma osmolality can be solved. Solving these two equations yield the equation,

$$
\mathbf{T}_{(\mathrm{cm})}=\mathbf{0 . 7 5} \mathbf{P}_{\mathrm{AVP}}+\mathbf{1 . 2}
$$

The result of this work shows that the above equation relating thirst perception and plasma arginine vasopressin exists and has a mean lower set point of 'not thirsty' or 'not having a desire to drink' of $1.2 \mathrm{~cm}$. Table 1 shows a mean of $1.21 \pm$ $0.15 \mathrm{~cm}$ for males and $1.10 \pm 0.16 \mathrm{~cm}$ for females.

From Thompson's et al equations (1986), the values of some plasma osmolality $\left(\mathrm{P}_{\text {osm }}\right)$ and their corresponding thirst $(\mathrm{cm})$, and also corresponding plasma arginine vasopressin $\left(\mathrm{P}_{\mathrm{AvP}}\right)$ in $\mathrm{pmol} / \mathrm{l}$ are shown below in their respective equations.

$$
\begin{aligned}
& T(\mathrm{~cm})=0.3\left(P_{o s m}-281\right) ; \quad P_{A V P}=0.4\left(P_{O S M}-285\right) \\
& T(0)=\operatorname{Posm}(281) ; \quad P_{A V P(0)}=\operatorname{Posm}(285) \\
& T(1)=\operatorname{Posm}(284.33) ; \boldsymbol{P}_{A V P(0.3)}=\operatorname{Posm}(285.75) \\
& T(1.2)=\operatorname{Posm}(285) ; \boldsymbol{P}_{A V P(0.4)}=\operatorname{Posm}(286) \\
& T(1.5)=\operatorname{Posm}(286) ; \boldsymbol{P}_{A V P(0.5)}=\operatorname{Posm}(286.25) \\
& T(1.575)=\operatorname{Posm}(286.25) ; \boldsymbol{P}_{A V P(1)}=\operatorname{Posm}(287.5) \\
& T(1.95)=\operatorname{Posm}(287.5)
\end{aligned}
$$

The osmotic threshold for thirst, which Thompson and his colleagues (1986) reported means that after $0 \mathrm{~cm}$ mark on the VAS there should be a sensation of thirst or a desire to drink water. The observed data of this study shows a TP of $1.21 \pm 0.15 \mathrm{~cm}$ for males and $1.10 \pm 0.16 \mathrm{~cm}$ for females as 'not having a desire to drink water' or 'not thirsty' and our derived equation shows a value of $1.2 \mathrm{~cm}$ as 'not having a desire to drink water' or 'not thirsty'. Since 'threshold' means the adequate stimulus required to cause an impulse or sensation, in this case to actually want to drink water, the $0 \mathrm{~cm}$ mark on the VAS cannot be said to be the threshold for thirst, but rather the lower set point of the scale for thirst perception. The threshold for TP on the VAS, from this study and from the derived equation, lies between a TP of $1.50-1.575 \mathrm{~cm}$ marking on the VAS. Markings of $0.0-150 \mathrm{~cm}$ on the visual analogue scale therefore are normal range for "not thirsty" or not having a desire to drink. Variations of individual markings on the lower end of the VAS could be due to differences in volume status of the subject.

It was also reported that plasma arginine vasopressin release is dependent on plasma osmolality and that the osmotic threshold of vasopressin secretion into the circulation is a plasma osmolality of $285 \mathrm{mOsm} / \mathrm{kg}$, (Thompson et al, 1986) or $284.3 \mathrm{mOsm} / \mathrm{kg}$ in healthy man (Thompson \& Mckenna, 1998). From the values shown in the equations above, at a plasma osmolality of $285 \mathrm{mOsm} / \mathrm{kg}$ there is no appreciation of thirst and there is no marked arginine vasopressin secretion, which means that the plasma osmolality is not yet high enough to give a sensation of thirst and subsequent plasma arginine vasopressin secretion to conserve body fluid. Our analysis shows that given plasma osmolality, arginine vasopressin and thirst, the important factor in stimulating thirst is increase plasma osmolality, and it has a normal range of 'not thirsty' between 280.0 - $285 \mathrm{mOsm} / \mathrm{kg}$ with a threshold of $286.0-286.25 \mathrm{mOsm} / \mathrm{kg}$. It is therefore concluded that the plasma osmolality of $281 \mathrm{mOsm} / \mathrm{kg}$ cannot be the threshold for thirst perception and the plasma osmolality of 285 $\mathrm{mOsm} / \mathrm{kg}$ or $284.3 \mathrm{mOsm} / \mathrm{kg}$ cannot be the threshold for plasma arginine vasopressin secretion but rather the mean of the lower set points on the scales for thirst perception and plasma arginine vasopressin secretion.

In summary, the sensation of thirst is closely associated with a dry mouth. The relationship: Thirst $(\mathrm{cm})=0.75$ (plasma arginine vasopressin +1.2 ) exists, and the lower set point of "not thirsty" on the VAS has a mean value of 
$1.2 \mathrm{~cm}$ thirst perception, and $285 \mathrm{mOsm} / \mathrm{kg}$ of plasma osmolality. The work of Thompson et al (1986) shows the mean of the lower set point for plasma osmolality on the relation between thirst and plasma osmolality to be $281 \mathrm{mOsm} / \mathrm{kg}$ and the mean of the lower set point on the relationship between plasma osmolality and plasma arginine vasopressin to be $285 \mathrm{mOsm} / \mathrm{kg}$. The threshold for thirst perception using the VAS lies between thirst perceptions of $1.50-1.575 \mathrm{~cm}$ markings on the VAS, plasma osmolality of 286.0 - 286.25 $\mathrm{mOsm} / \mathrm{kg}$ and plasma arginine vasopressin of 0.4 $0.5 \mathrm{pmol} / \mathrm{l}$ being the sensitivity of the osmoregulatory unit. Markings of $0.0-1.4 \mathrm{~cm}$ on the VAS, and plasma osmolality of $281-285$ $\mathrm{mOsm} / \mathrm{kg}$ are normal ranges of not thirsty.

\section{REFERENCES}

Adolp E.F. (1947): In: Thirst Physiological And Psychological Aspects, Eds. D. J. Ramsay And D. A. Booth, 382 - 390, Springer Verlag, London, 1991.

Baylis P.H. and Robertson G.L (1980): Plasma Vasopressin Response To Hypertonic Saline Infusion To Assess Posterior Pituitary Function. Journal Of The Royal Society Of Medicine, 73:255-260.

Bellows R.T. (1939): Time Factors In Water Drinking In Dogs. Am. J.Physiol.125:87-97.

Bernard C. (1856): In: Thirst-Problems In The Behavioral Sciences By Rolls B.J And Rolls E.T. Cambridge University Press, Cambridge, 1982.

Burrell L.M., Lambert H.J and Baylis P.H. (1991): The Effect Of Drinking On Atrial Natriuretic Peptide, Vasopressin And Thirst Appreciation In Hyperosmolar Man. Clin. Endocr. 35:229-234.

Canon W.B. (1919): The Physiological Basis Of Thirst. Proceedings Of The Royal Society, London (1992), 90:283-301.

Epstein A.N., Spector D., Samman A., And Goldblum C. (1964): Exaggerated Prandial Drinking In Rats Without Salivary Glands. Nature, 201:1324 -3.

Figaro M. K and Mack G.W. (1997): Regulation Of Fluid Intake In Dehydrated Humans: Role Of
Oropharyngeal Stimulation. Am. J. Physiol. 272 (41): R1740 - R1746.

Fizsimons J.T. (1972): Thirst. Physiol Rev. 52:468 - 561.

Frohlich E. D., Grim C., Labarthe D.R., Maxwell M.H., Perloff D. And Weidman W. H. (1988): Recommendations For Human Blood Pressure Determination By Sphgmomanometers. Circulation. 77: 502A - 514A.

Gairdner (1925): In Thirst - Problems In The Behavioural Sciences By Rolls B.J And Rolls E.T. Cambridge University Press, Cambridge, 1982.

Grossman S.P. (1967): A Textbook Of Physiological Psychology, New York: John Wiley And Sons, Page 88

Haller A. (1764): In Thirst-Problems In The Behavioural Sciences By Rolls B.J And Rolls E.T, Cambridge University Press, Cambridge 1982.

Kokkinos P.F., Narayan P., Colleran J.A., Pittaras A., Notargiacomo A., Reda D. And V. Papademetrious (1995): Effects Of Regular Exercise On Blood Pressure And Left Ventricular Hypertrophy In African-American Men With Severe Hypertension. N.Engl. J. Med.333:14621467.

Mc Kenna K. and Thompson C. (1998): Osmoregulation In Clinical Disorders Of Thirst Appreciation. Clin. Endocr. 49:139-152.

Montgomery M.F. (1931): The Role Of The Salivary Glands In The Thirst Mechanism. Am. J. Physiol. 96:221-7

Obika L.F.O., Babatunde E.O., Akoni F.A., Adeeko A.O., Nsaho J., Reza H. And Williams S.A. (1996): Kolanut Enhances Antidiuretic Activity In Young Dehydrated Subjects. Phytotheraphy Research 10:563-568.

Peyreigne C., Bouix D., Micallef J.P., Mercier J., Bringer J., Prefaut C And Brun J. F. (1998): Exercise-Induced Growth Hormone Secretion And Hemorheology During Exercise In Elite Athletes. Clin. Hemorh. \& Microcirc 19:169-176.

Robertson G.L., Shelton R.L And Athar. S. (1976): The Osmoregulation Of Vasopressin. Kidney International 10:25-37.

Robertson G. L., Aycinena P. R And Zerbe R. I. (1982): Neurogenic Disorders Of Osmoregulation. Am. J. Med. 72: 339 - 353.

Robertson G.L. (1984): Abnormality Of Thirst 
Regulation. Kidney International 25:460-469

Rolls B.J., Wood R. J., Roll E. T., Lind H., Lind W., Ledingham J. G. G (1980): Thirst Following Water Deprivation In Humans. Am. J. Physiol. 239:R476-R482

Rolls B. J. And Rolls E. T. (1982): Thirst: Problems In The Behavioural Sciences. Cambridge University Press, Cambridge, Page 54.

Stachenfeld N. S., Mack G. W., Takamata A., Dipietro. L. And Nadel E. R. (1996): Thirst And Fluid Regulatory Responses To Hypertonicity In Older Adults. Am J. Physiol.271 (40): R757R765.

Steggerda F.R. (1941): Observations On The Water Intake In An Adult Man With Dysfunctioning Salivary Glands. Am. J. Physiol. 132:517-21

Takamata A., G.W. Mark, C.M. Gillen And E.R. Nadel (1994): Sodium Appetite, Thirst And Body Fluid Regulation In Humans During
Rehydration Without Sodium Replacement. Am. J. Physiol. 266 (35): RI493 - R1502.

Thompson D. A. and Campbell R.G. (1977): Hunger In Humans, Induced By 2-Deoxy-DGlucose: Glucoprivic Control Of Taste Preference And Food Intake. Science 198:1065-1068.

Thompson C. J., Bland J., Burd J. \& Baylis P.H (1986): The Osmotic Thresholds for Thirst and Vasopressin Release Are Similar in Healthy Man .Clin. Sci. 71:651-656.

Thompson C. J (1989): Polyuric States In Man. Clinics In Endocr And Metabolism 3:473-497.

Thompson C. J. Selby P and Baylis P.H. (1991): Reproducibility Of Osmotic And Non-Osmotic Tests Of Vasopressin Secretion In Man. Am J. Physiol. 260:R533-R539

Wolf A.V. (1958): Thirst: Physiology Of The Urge To Drink And Problems Of Water Lack. Springfield Ill: Thomas Edition, Page 28. 